\title{
Six Sigma Analysis as an Approach to Improve Quality of Corrugated Zinc Sheet Product
}

Handy Nur Cahya ${ }^{1 凶}$

1 Department of Management, Faculty of Economics and Business, Dian Nuswantoro University, Indonesia

\section{Article Information}

Article history:

Accepted: April 2021

Approved: July 2021

Published: September 2021

Keywords:

six sigma

DMAIC

product defect

quality control

manufacturing

\begin{abstract}
Every manufacturing company will strive to create the best quality products. This is also done by PT. CMSM, a steel company, is producing corrugated zinc products. In several production periods, the defective product values were still found that exceeded the tolerance limit value set at $0.5 \%$ in corrugated zinc products. These problems are, of course, very detrimental to the company, so it's essential to control the quality of corrugated zinc products. This study aimed to determine the factors that cause product defects, propose plans to improve product quality, and provide managerial recommendations based on Six Sigma analysis. Data collection techniques are carried out through observation, interviews, and documentation. Based on the study results, it is known that DPO is 0.000885 and DPMO is 884.6028. At this time, the company is at the level of 4.64 sigma with CTQ (Critical to Quality) folded zinc sheet, cut size is not according to standard, thickness is not according to standard, uneven coating layer and perforated zinc sheet. Based on the analysis, five factors cause product defects: humans, machines, methods, materials, and the environment. To improve quality, the company should improve their quality control through $5 W+1 \mathrm{H}$ analysis, namely by providing training to employees, periodic machine maintenance and ensuring that the SOPs that have been made are implemented correctly and adequately.
\end{abstract}

How to Cite: Cahya, H. (2021). Six Sigma Analysis as an Approach to Improve Quality of Corrugated Zinc Sheet Product. Jurnal Penelitian Ekonomi dan Bisnis, 6(2), 75-89. doi:https://doi.org/10.33633/jpeb.v6i2.4638

\begin{tabular}{lr}
\hline correspondence address: & ISSN \\
Fakultas Ekonomi dan Bisnis, Universitas Dian Nuswantoro. & $2442-5028$ (print) 2460-4291 \\
Jalan Nakula 1 nomor 5-11, Pendrikan Kidul, Semarang & (online) \\
E-mail: handy.nur@dsn.dinus.ac.id & DOI: 10.33633/jpeb.v6i2.4638
\end{tabular}

E-mail: handy.nur@dsn.dinus.ac.id 


\section{INTRODUCTION}

Product quality is one of the benchmarks for improving product purchasing decisions (Schmuck \& Benke, 2020). So, companies must constantly make innovations to improve the quality of the products produced (GUAN et al., 2009), through manufacturing, using high-quality material, or even by regularly doing innovation (Prendeville \& Bocken, 2017). Quality products will increase customer satisfaction (Suresh \& Vasantha, 2021) so repeat purchases will occur (Hsu et al., 2015; Kunamaneni et al., 2019) and create long-term cooperative relationships that can increase profits for the company (Navío-Marco et al., 2019; Tremblay et al., 2019). To create quality products, companies are required to be able to optimize the use of their resources (Lyu et al., 2020) efficiently by using effective methods so that companies can create quality products by optimizing the use of their resources without having to spend a lot of money to buy additional resources (Herron \& Hicks, 2008; Pyzdek \& Keller, 2013; Romdony et al., 2018).

The manufacturing process consists of 3 stages (Gaspersz, 2005; Malviya, 2021), namely Input, Process, and Output. There are often problems with products that do not meet good quality product standards (defects). Products that do not pass the quality test will undoubtedly cause a lot of harm to the company because these products must be recycled or destroyed. Defective products can cause additional production costs (Jirasukprasert et al., 2015; Younge \& Tong, 2018), so that the number of defective products as much as possible must be reduced to near zero value so that the company can minimize additional production costs.

According to data in the Indonesian Ministry of Industry, 316 industries have been registered (Kementrian Perindustrian Indonesia, 2020). Based on The World Steel Association, it was noted that in 2019 Indonesia was in the 26th position in the world for processing raw steel products with a total production of 6.4 million tons. The processed steel products also range from zinc-coated steel, lightweight steel roof trusses, iron pipes, frame beams, and so on (World Steel Association, 2019). PT. CMSM is a company engaged in the light steel processing sector, which has been operating since 2011 and started producing commercial products in 2014, It has 80 employees in the production sector with a 3-shift work system and 22 employees in the managerial sector, located on Cikarang, Bekasi, West Java. There are two types of products made: corrugated zinc sheet steel $0.20 \times 762$ and plain zinc steel $0.20 \times 914$. The optimal production capacity for corrugated zinc is 4,000 tons/month and produces 800,000 pcs / month.

Based on the data obtained along with observation, it shows that the corrugated zinc product defects are still above the reasonable threshold set by the company of $0.5 \%$, so this study is carried out to understand what this causes. Products that do not pass the quality control check cannot be further processed for packaging at the warehouse, so they must be melted back to be reproduced (recycled). Based on the data collected, the number of defect products in several production periods still exceeded the maximum allowable limit, the data could be seen in Table 1.

Based on data on defect products in October, November, and December 2019, the highest number of defect products was in October 2019, with an average value of $0.5393 \%$, while in November 2019 was $0.3666 \%$. Followed by December 2019 was 0, 3977\% tends to be stable below the tolerance threshold that the company of $0.5 \%$ has set. We use late 2019 production data in this study, as the company keeps the last-one-year-production data confidential, so the shareable data is the 2019 production recap.

According to Render \& Heizer (Heizer, Jay., 2017), several methods can be used to overcome defect product problems, including Continuous Improvement, Kaizen, and Six Sigma. Continuous Improvement and Kaizen methods overcome quality problems by taking continuous improvement actions on production parts that are not yet optimal to reduce the number of defective products (Render \& Heizer, 2001). The Continuous Improvement and Kaizen will be efficiently applied if the factors causing the appearance of defective products are known (Prendeville \& Bocken, 2017; Tjiptono, F., dan Diana, 2012; Tjiptono, 2003), so that the focus of improvement can be optimized on the causes of defect products.

Six Sigma methodology can diagnose the root of the problem, both in quality improvement and processing time efficiency (Desai, 2017; Jirasukprasert et al., 2015). Six Sigma is a methodology that focuses on eliminating the causes of variations or defects in a product or production process (Martin, 2008). In today's dynamic industry, quality alone is not enough to achieve customer satisfaction (Ferreira et al., 2015), however, supply of good quality goods must be delivered consistently according to the delivery schedule (Desai, 2017; Lyu et al., 2020). According to De Mast (Marques \& Matthé, 2017) 
the production process has reached perfection based on six sigma if it only produces no more than 3.4 defects out of 1,000,000 opportunities (defects per million opportunities). However, this is undoubtedly very difficult to achieve. So, company tend to focus to minimize defective product to near zero (zero defects).

Table 1. Product data that did not pass the quality control for wave type corrugated zinc sheet production for the period of October 2019 to December 2019

\begin{tabular}{|c|c|c|c|}
\hline Periods & $\begin{array}{l}\text { Amount of } \\
\text { Production }\end{array}$ & $\begin{array}{l}\text { Amount of Product } \\
\text { Defect }\end{array}$ & Percentage (\%) \\
\hline \multicolumn{4}{|l|}{ October } \\
\hline Oct week 1 & 142.515 & 653 & $0,4584 \%$ \\
\hline Oct week 2 & 171.018 & 639 & $0,3741 \%$ \\
\hline Oct week 3 & 184.109 & 1.286 & $0,699 \%$ \\
\hline Oct week 4 & 165.048 & 605 & $0,367 \%$ \\
\hline \multirow[t]{2}{*}{ Oct week 5} & 163.934 & 1.308 & $0,798 \%$ \\
\hline & & average & $0,5393 \%$ \\
\hline \multicolumn{4}{|l|}{ November } \\
\hline Nov week 1 & 0 & 0 & 0 \\
\hline Nov week 2 & 201.697 & 630 & $0,3126 \%$ \\
\hline Nov week 3 & 178.211 & 512 & $0,2874 \%$ \\
\hline Nov week 4 & 188.684 & 715 & $0,3794 \%$ \\
\hline \multirow[t]{2}{*}{ Nov week 5} & 224.245 & 1092 & $0,4871 \%$ \\
\hline & & average & $0,3666 \%$ \\
\hline \multicolumn{4}{|l|}{ December } \\
\hline Dec week 1 & 219.784 & 631 & $0,2874 \%$ \\
\hline Dec week 2 & 189.647 & 717 & $0,3785 \%$ \\
\hline Dec week 3 & 197.341 & 961 & $0,4872 \%$ \\
\hline Dec week 4 & 213.519 & 934 & $0,4378 \%$ \\
\hline Dec week 5 & 0 & 0 & 0 \\
\hline
\end{tabular}

Source: Company weekly production data, 2020.

Pyzdek and Keller (Pyzdek \& Keller, 2013) explain the advantages implementing Six Sigma: reduced costs, improved cycle times, elimination of products that do not pass the quality test, increased customer satisfaction and a significant increase in profit. Several previous studies have shown that using the Six Sigma method can significantly reduce product defects. Sharma (Sharma et al., 2018) explains that using the Six Sigma method efficiently increases the sigma value from 2.67 to 4.11 and increases quality products from $87.8 \%$ to $99.6 \%$ in one production period. This is also supported by research conducted by Punyawan and Rahardjo (Punyawan \& Rahardjo, 2015) that product defect percentage rates decreased from $0.11 \%$ to $0.073 \%$ after the Six Sigma method was applied.

To reduce the number of defective products to be consistently below the fair threshold value set by the company, an analysis is necessary to reduce the number of defective products. As discussed earlier, that Six Sigma can diagnose the root of the problem so that the problem can be resolved in a focused manner at the problematic point. The use of Six Sigma seems promising to help solve the issues currently being faced by the company.

Quality is a dynamic condition that combines products, processes, human resources, services, and the environment to produce a superior value product that exceeds consumers' expectations (Davis, 2010; Pyzdek \& Keller, 2013; Slack et al. 2016). Quality is also defined as a form and characteristics of a product in its totality that can show its ability to fulfill clear or hidden consumer needs(Heizer et al., 2017; Martin, 2008). 
The company needs to create a strategic system of how the steps should be taken and the essential points when implementing quality control (Choi, 2020). Strategy is needed because the determinants of quality consist raw materials, machines, production equipment, and labor which will cause varied effects on the final quality. So company needs to determine the suitable method in improving quality which can precisely target quality cost savings optimization (Ayhari, 2009; Kumar \& Suresh, 2007)

Pande and Roland R. Cavanagh (Pande \& Roland R.Cavanagh, 2002; Sharma et al., 2018) explain that Six Sigma is a concept that is almost close to perfection to meet consumer requirements. According to Gaspersz (Gaspersz, 2005) Six Sigma is a vision to improve quality towards a target of 3.4 errors from one million transaction periods for goods and services. So, by adopting the concept of Six Sigma in production process should be able to improve quality and reduce the error rate.

\section{METHOD}

There are five stages in implementing quality improvement using the Six Sigma method, namely using the Define, Measure, Analyze, Improve and Control (DMAIC) method (Pete \& Holpp, 2002). The Define stage is a step to analyze to determine the target where quality improvement using Six Sigma will be carried out. At this stage an action plan is drawn up and what must be done to improve each step of the process (Gaspersz, 2005). The Measure stage has three essential things that must be carried out: 1. Make a selection to determine the main quality characteristics (Critical to Quality) 2. Develop a plan to collect data 3. Measure the line of work at the output level. In the step of Analyze, things that must be done include 1. Determining the capabilities (capabilities) and stability of the process 2 . Determining performance targets and characteristics of key quality (CTQ) 3. Conducting identify the root causes and sources of problems that impede quality.

Followed by Improve stage, this step begins by establishing a plan regarding what actions will be taken to implement the Six Sigma concept on the targets set in the previous step. Quality improvement is also prioritized to reduce the DPMO value to near zero and increase the sigma value closer to the Six Sigma value (Gaspersz 2005). After all, we continue with Control as the last stage in the implementation of Six Sigma.

In this study, the population is the entire production of corrugated zinc steel from January 2019 - December 2019 at observed company. The samples in this study were corrugated zinc steel products that did not pass the quality test taken per week from October 2019 to December 2019.

Several methods of data collecting were used, including interviews, observation and documentation to gather a deep understanding of what is going on in the company. The analysis technique in this research is based on the principles of Six Sigma concepts. By using the DMAIC stage in Six Sigma, which are Define, Measure, Analyze, Improve, and Control, we can try to identify the cause of the problem, analyze the data, and formulate some fix to overcome the problem (Pete \& Holpp, 2002).

\section{RESULT AND DISCUSSION \\ Define}

This research is carried out by follows the principles of DMAIC in Six Sigma. The very first stage in DMAIC is Define, followed by Measure, Analyze, Improve, and Control. The Define stage is the stage that describes the defect product problems which occurred in the corrugated zinc production. In the Define stage, we used data from the pre-survey, which explains the operational production flow, arranged in a SIPOC diagram in Figure 1.

Based on the interview with the production manager on the production site, Mr. Winarto, there are five types of defect classifications. The first defect category is UCL (Uneven Coating Layer), the second defect category is FZS (Folded Zinc Sheet), the third defect type is PZS (Perforated Zinc Sheet), the fourth defect type is CNFS (Cut Size Does Not Fit the Standard) and Type The last defect is TNFS (Thickness Does Not Appropriate to Standard). 


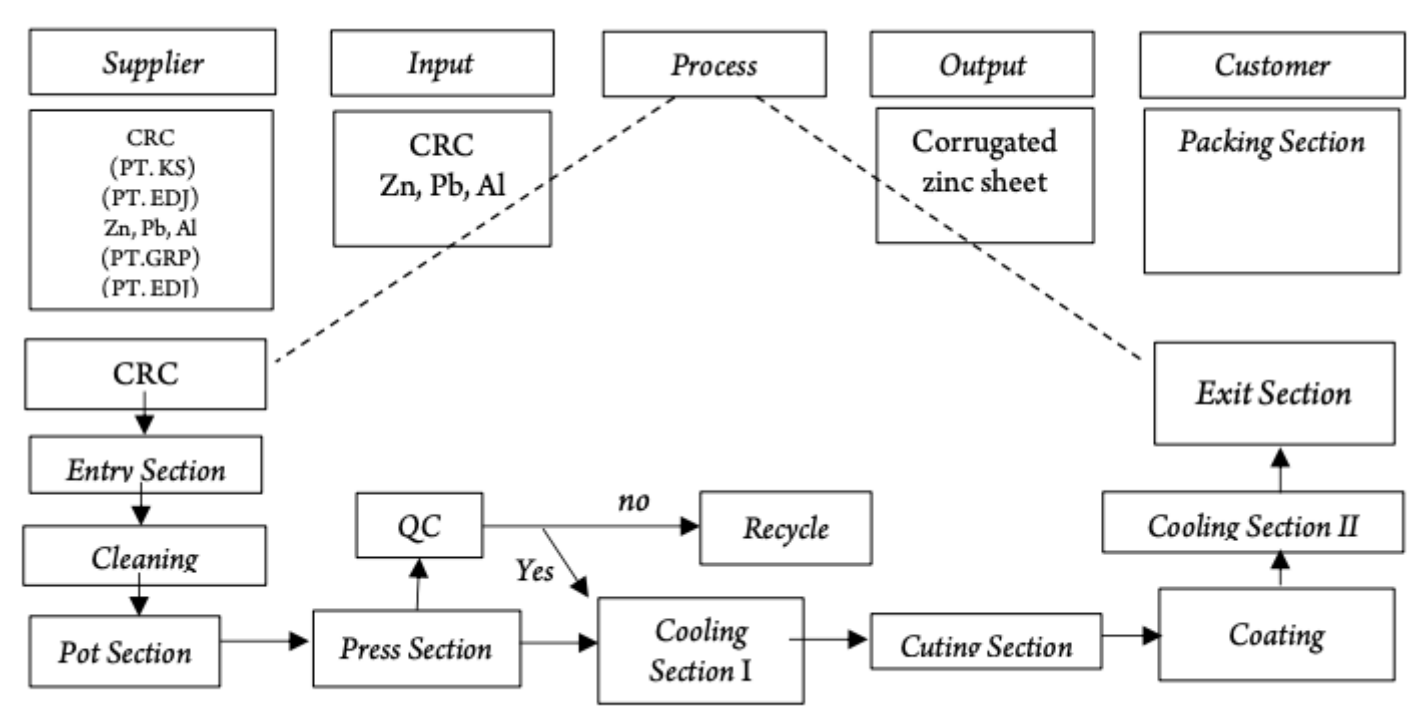

Figure 1. SIPOC Diagram of Zinc Wave Production Source: Primary data, 2020

\section{Measure}

The Measure stage is carried out in two phases. The first stage is to process defect product data for October 2019 - December 2019 with a control chart (p-chart) and in the second stage by calculating the value of Defect per Million Order (DPMO) (Anthony, 2017). The calculation of the control limit (CL), upper control limit (UCL), and lower control limit (LCL) are based on the following applicable formula (Gaspersz, 2005):

Control Limit week one:

$$
\begin{aligned}
& \mathrm{CL}=\overline{\mathrm{p}}=\frac{\sum \text { Defect products }}{\sum \text { total productions }} \\
& \mathrm{CL}=\overline{\mathrm{p}}=\frac{10683}{2439752} \\
& \mathrm{CL}=\overline{\mathrm{p}}=0,00437872
\end{aligned}
$$

Upper Control Limit week one:

$$
\begin{aligned}
\mathrm{UCL} & =\overline{\mathrm{p}}+3 \sqrt{\frac{\overline{\mathrm{P}}(1-\overline{\mathrm{P}})}{\mathrm{n}}} \\
\mathrm{UCL} & =0,0044+3 \sqrt{\frac{0,0044(1-0,0044)}{142515}} \\
\mathrm{UCL} & =0,00407938
\end{aligned}
$$

Lower Control Limit week one:

$$
\begin{aligned}
\mathrm{LCL} & =\overline{\mathrm{p}}-3 \sqrt{\frac{\overline{\mathrm{P}}(1-\overline{\mathrm{P}})}{\mathrm{n}}} \\
\mathrm{LCL} & =0,0039-3 \sqrt{\frac{0,0044(1-0,0044)}{142515}} \\
\mathrm{LCL} & =0,00385402
\end{aligned}
$$

This calculation is repeated for all data available using the same method, and the result can be found in Table 2 below: 
Table 2. Calculation Results Data CL, UCL and LCL

\begin{tabular}{lcccccr}
\hline Time Frame & $\begin{array}{c}\text { Amount of } \\
\text { Production }\end{array}$ & $\begin{array}{c}\text { Amount } \\
\text { of Defect }\end{array}$ & Proportion & CL & UCL & LCL \\
\hline Oct week 1 & 142.515 & 653 & 0,0046 & 0,0044 & 0,0049 & 0,0039 \\
Oct week 2 & 171.018 & 639 & 0,0037 & 0,0044 & 0,0049 & 0,0039 \\
Oct week 3 & 184.109 & 1.286 & 0,0070 & 0,0044 & 0,0048 & 0,0039 \\
Oct week 4 & 165.048 & 605 & 0,0037 & 0,0044 & 0,0049 & 0,0039 \\
Oct week 5 & 163.934 & 1.308 & 0,0080 & 0,0044 & 0,0049 & 0,0039 \\
Nov week 1 & 0 & 0 & 0 & 0 & 0 & 0 \\
Nov week 2 & 201.697 & 630 & 0,0031 & 0,0044 & 0,0048 & 0,0039 \\
Nov week 3 & 178.211 & 512 & 0,0029 & 0,0044 & 0,0048 & 0,0039 \\
Nov week 4 & 188.684 & 715 & 0,0038 & 0,0044 & 0,0048 & 0,0039 \\
Nov week 5 & 224.245 & 1092 & 0,0049 & 0,0044 & 0,0048 & 0,0040 \\
Dec week 1 & 219.784 & 631 & 0,0029 & 0,0044 & 0,0048 & 0,0040 \\
Dec week 2 & 189.647 & 717 & 0,0038 & 0,0044 & 0,0048 & 0,0039 \\
Dec week 3 & 197.341 & 961 & 0,0049 & 0,0044 & 0,0048 & 0,0039 \\
Dec week 4 & 213.519 & 934 & 0,0044 & 0,0044 & 0,0048 & 0,0040 \\
Dec week 5 & 0 & 0 & 0 & 0 & 0 & 0 \\
\hline Source: Prim & 0 & & & & 0 & 0 \\
\hline
\end{tabular}

Source: Primary data (processed), 2020

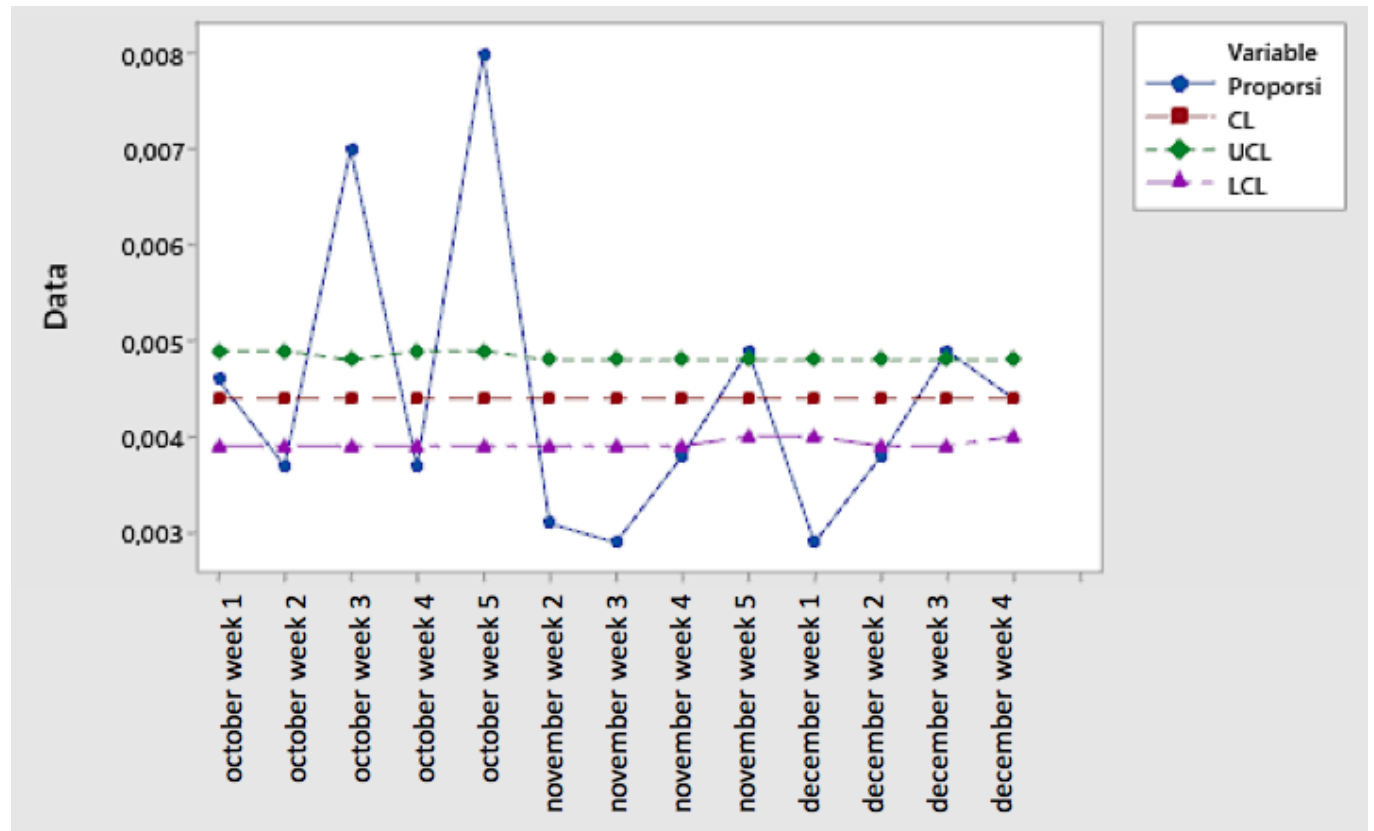

Figure 2. Control Diagram

Source: Primary data (processed), 2020

Figure 2 above shows the proportion of defects. Several productions periods show defect proportion value exceeds the upper control limit and the lower control limit. They are October week three and October week five significantly pointing far higher than the upper control limit. And the other side, November week two, November week three and December week one, point far below the lower control limit. 
The value that comes out of the upper control limit (UCL) and lower control limit (LCL) areas can be considered undesirable values (Indrawati \& Isnaini Dwi Ningsih, 2018). This shows that the production process is in an unstable condition. So further analysis is needed to determine the factors causing this instability in the production process.

Table 3. Calculation of DPO, DPMO and Sigma Level

\begin{tabular}{lcccccc}
\hline Time Frame & $\begin{array}{c}\text { Amount of } \\
\text { Production }\end{array}$ & $\begin{array}{c}\text { Amount } \\
\text { of Defect }\end{array}$ & CTQ & DPO & DPMO & $\begin{array}{c}\text { Sigma } \\
\text { Level }\end{array}$ \\
\hline Oct week 1 & 142.515 & 653 & 5 & 0,000916 & 916,3948 & 4,62 \\
Oct week 2 & 171.018 & 639 & 5 & 0,000747 & 747,2898 & 4,68 \\
Oct week 3 & 184.109 & 1.286 & 5 & 0,001397 & 1396,999 & 4,49 \\
Oct week 4 & 165.048 & 605 & 5 & 0,000733 & 733,1201 & 4,68 \\
Oct week 5 & 163.934 & 1.308 & 5 & 0,001596 & 1595,764 & 4,45 \\
Nov week 1 & 0 & 0 & 0 & 0 & 0 & 0 \\
Nov week 2 & 201.697 & 630 & 5 & 0,000625 & 624,6994 & 4,73 \\
Nov week 3 & 178.211 & 512 & 5 & 0,000575 & 574,5998 & 4,77 \\
Nov week 4 & 188.684 & 715 & 5 & 0,000758 & 757,8809 & 4,68 \\
Nov week 5 & 224.245 & 1092 & 5 & 0,000974 & 973,9348 & 4,6 \\
Dec week 1 & 219.784 & 631 & 5 & 0,000574 & 574,2001 & 4,75 \\
Dec week 2 & 189.647 & 717 & 5 & 0,000756 & 756,1417 & 4,68 \\
Dec week 3 & 197.341 & 961 & 5 & 0,000974 & 973,9486 & 4,6 \\
Dec week 4 & 213.519 & 934 & 5 & 0,000875 & 874,8636 & 4,63 \\
Dec week 5 & 0 & 0 & 0 & 0 & 0 & 0 \\
& Averages & & & $\mathbf{0 , 0 0 0 8 8 5}$ & $\mathbf{8 8 4 , 6 0 2 8}$ & $\mathbf{4 , 6 4}$ \\
\hline
\end{tabular}

Source: Primary data (processed), 2020

Based on the results of DPMO calculations on corrugated zinc production available on Table 3, we got average value of 884,6028 . This value then converted into a table of Sigma Level which classified as 4.64 sigma. This means continuous improvement is needed to reach the 6-sigma level.

\section{Analyze}

In the Analyze stage, the root causes of defect products are identified using Pareto diagrams and causal diagrams. The Pareto diagram is used to determine the proportion of the most dominant type of defect. In contrast, the cause-and-effect diagram determines the factors that cause the appearance of defect products. Before further analyze, Table 4 below show the result of Calculation of Defect Products.

Table 4. Result of Calculation of Defect Products

\begin{tabular}{lcc}
\hline \multicolumn{1}{c}{ Defects Classification } & Amount of Defect & Percentage \\
\hline Folded zinc sheet (FZS) & 4545 & $42,54 \%$ \\
Cut size does not meet standard (CNMS) & 4077 & $38,16 \%$ \\
Thickness not meet up to standard (TNMS) & 1074 & $10,05 \%$ \\
Uneven coating layer (UCL) & 609 & $5,70 \%$ \\
Perforated zinc sheet (PZS) & 378 & $3,54 \%$ \\
\multicolumn{1}{c}{ TOTAL } & $\mathbf{1 0 6 8 3}$ & $\mathbf{1 0 0 \%}$ \\
\hline
\end{tabular}

Source: Primary data, 2020 
Based on the Table 4, there are five main types of defects, namely: Folded Zinc Sheet (FZS) of 42.54\%, Cut Size Does Not Appropriate to Standard (CNMS) by 38.16\%, Thickness Does Not Appropriate to Standard (TNMS) by 10.05\%, Uneven Coating Layer (UCL) of $5.70 \%$ and $3.54 \%$ for Perforated Zinc Sheet (PZS). The proposed improvement will focus on the five types of defects because these defects have a significant impact on the quality of the output produced.

Knowing those problem, the next stage of this research is carried out by finding the cause of the problem. The fishbone diagram is then used to determine what factors are the causes of defect products in the wave zinc production process (Ayhari, 2009). At the stage of compiling the cause-and-effect diagram, interviews conducted with production labor on the site. The purpose involving the direct labor on the production site is to make sure that we got valid information causing those all problem, as the labor on production site are the one who have daily contact with all of those problems. The interview discusses the factors causing defects in the wave zinc production process. Every main problem we discussed earlier are meant to be discussed with labor on site to gain deep understanding about what is causing the problem. The result is then described in the following fishbone diagram. The result can be seen as in Figure 4 to Figure 8 shown below.

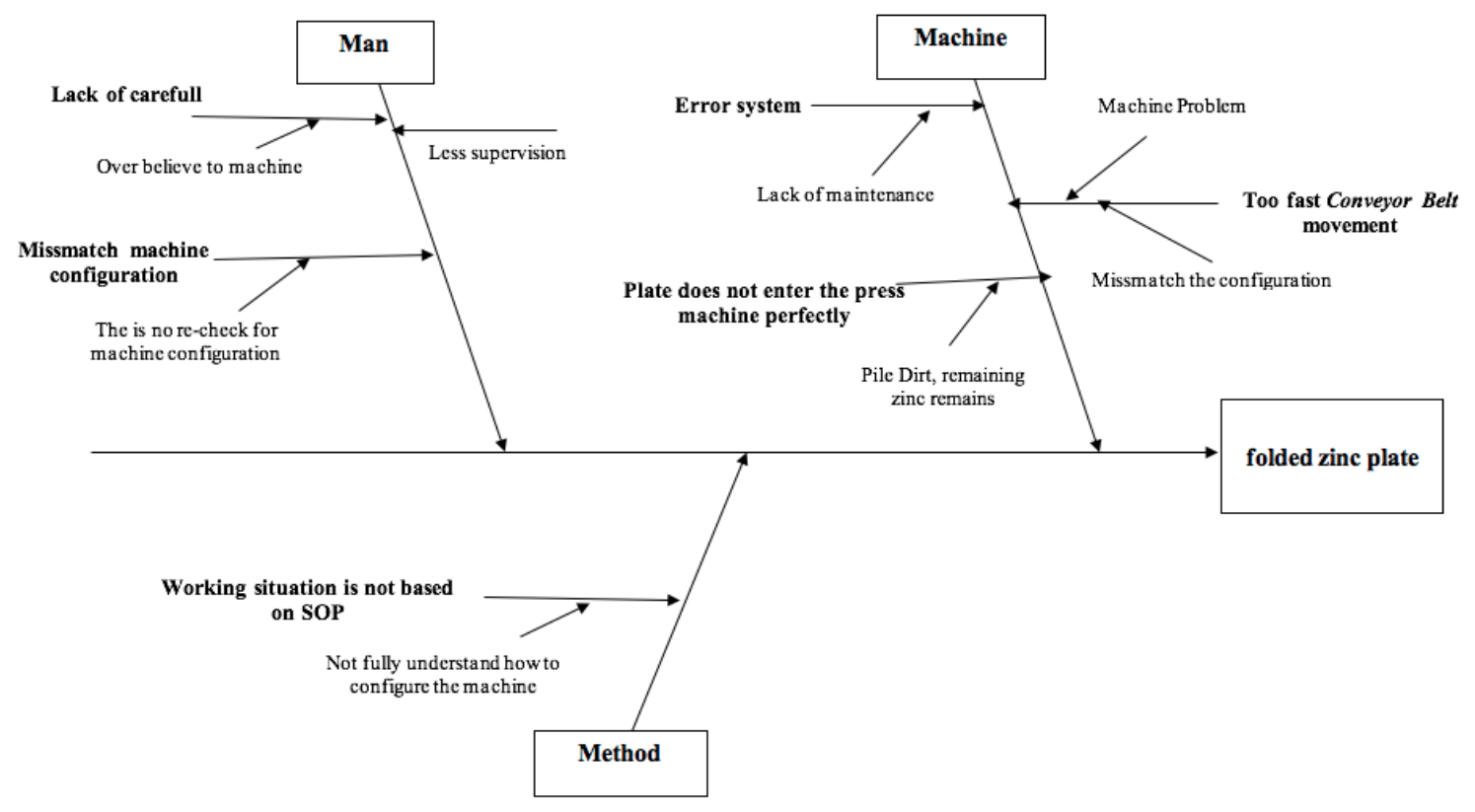

Figure 4. Cause and Effect Diagram of Folded Zinc Sheet

Source: Primary data (processed), 2020

Figure 4 shows the result of what causing the problem of Folded Zinc Place. There are 3 factor causing folded zinc plate often re occurred in the process of production. They are man factor, machine factor, and method factor. On the Man factor, we can understand the root causing problem, such lack of careful caused by less supervision and, the labor itself tend to over believe to the machine, so they tent just to ignore and does not performing check and recheck for the configuration. Machine factor can we understand caused by system error because of lack of maintenance, no regular maintenance is performed, and so on. Sometimes the conveyor belt just moves to fast, this caused by the labor does not perform check and re check so that the configuration does not fit to the changing materials being processed. This is also caused by the method because the labor does not always follow the SOPs available in performing each task. 


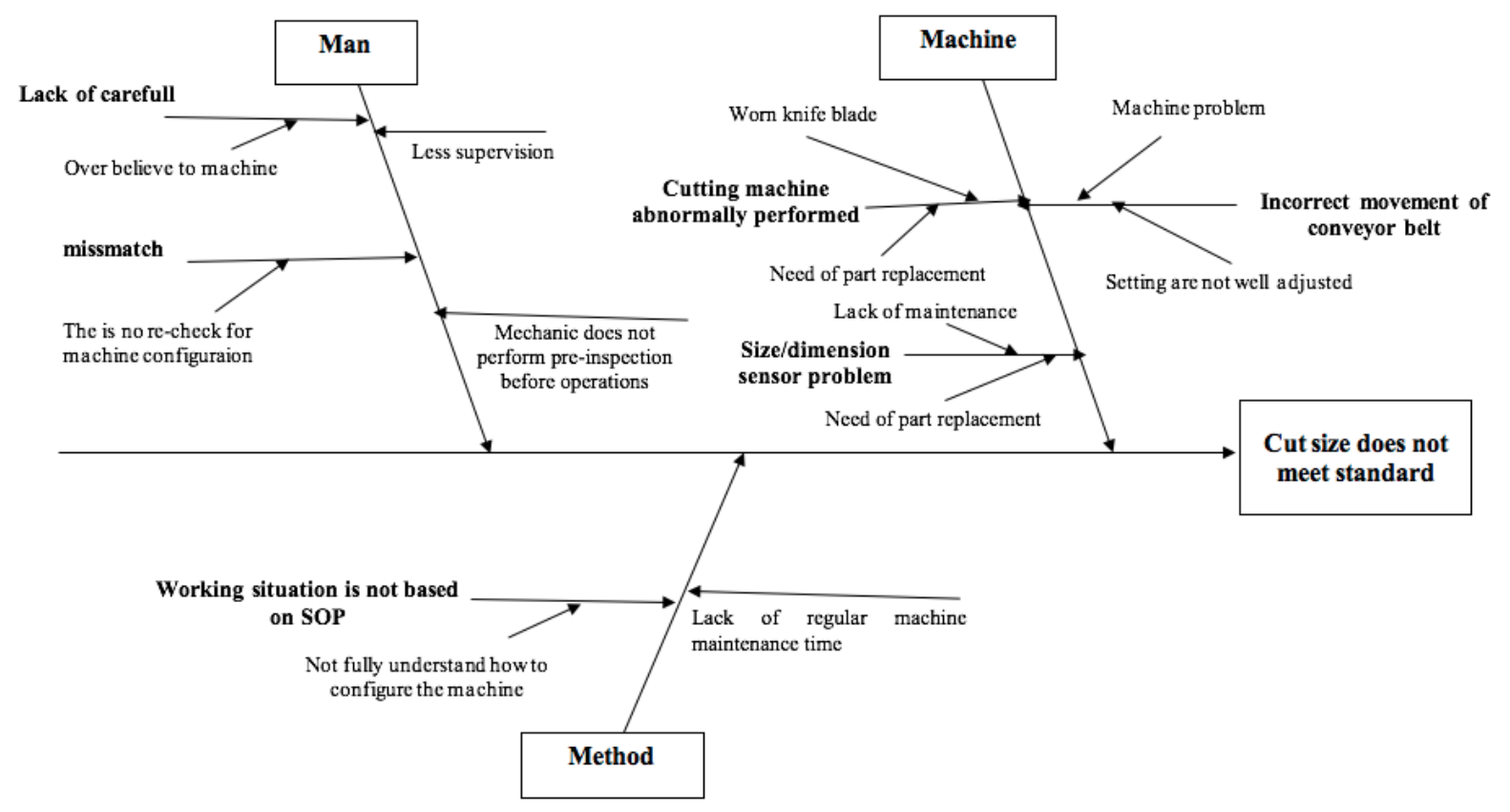

Figure 5. Cause and Effect Diagram of Cut Size Does Not Appropriate to Standard Source: Primary data (processed), 2020

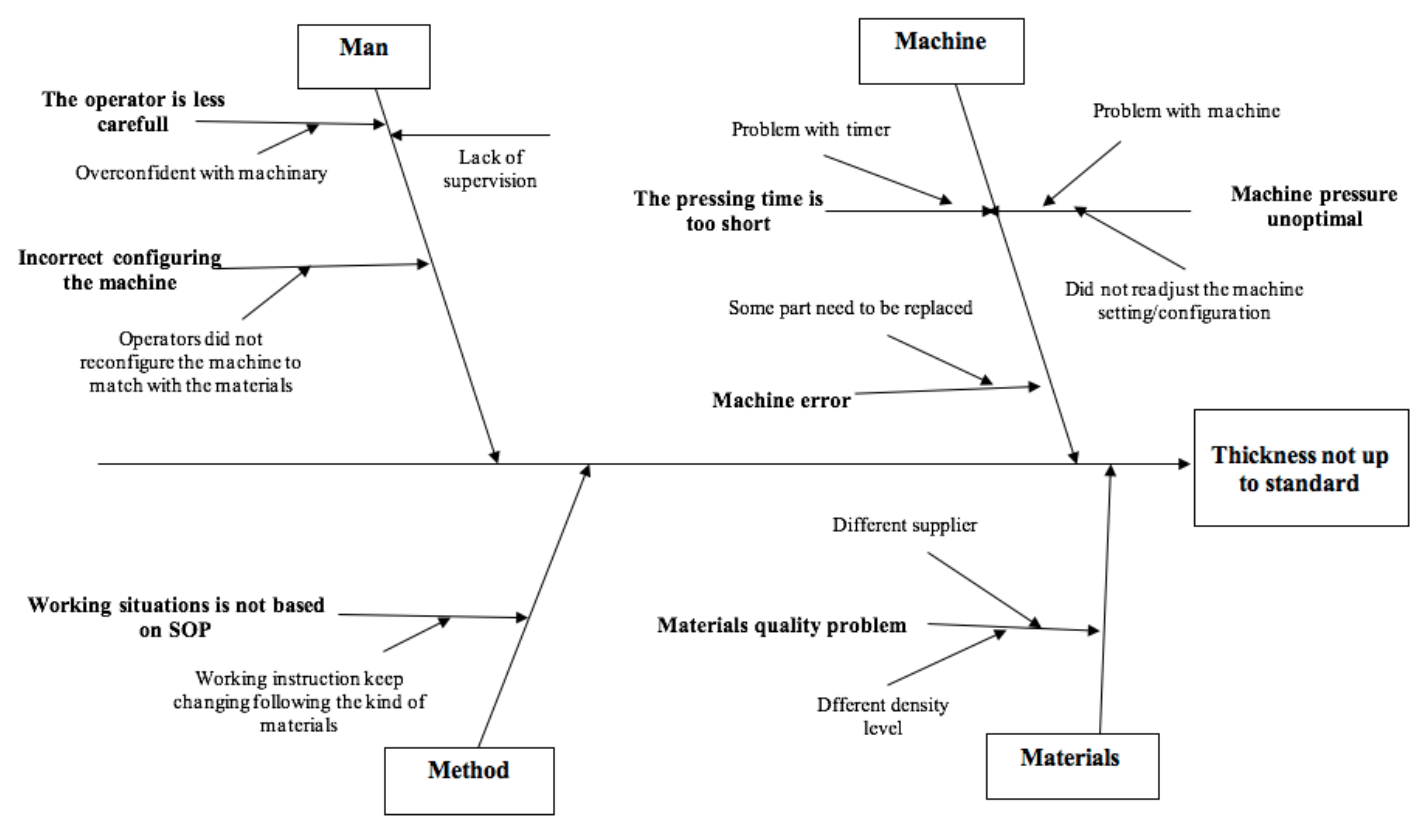

Figure 6. Cause and Effect Diagram of Thickness Not Meet Up to Standard Source: Primary data (processed), 2020 


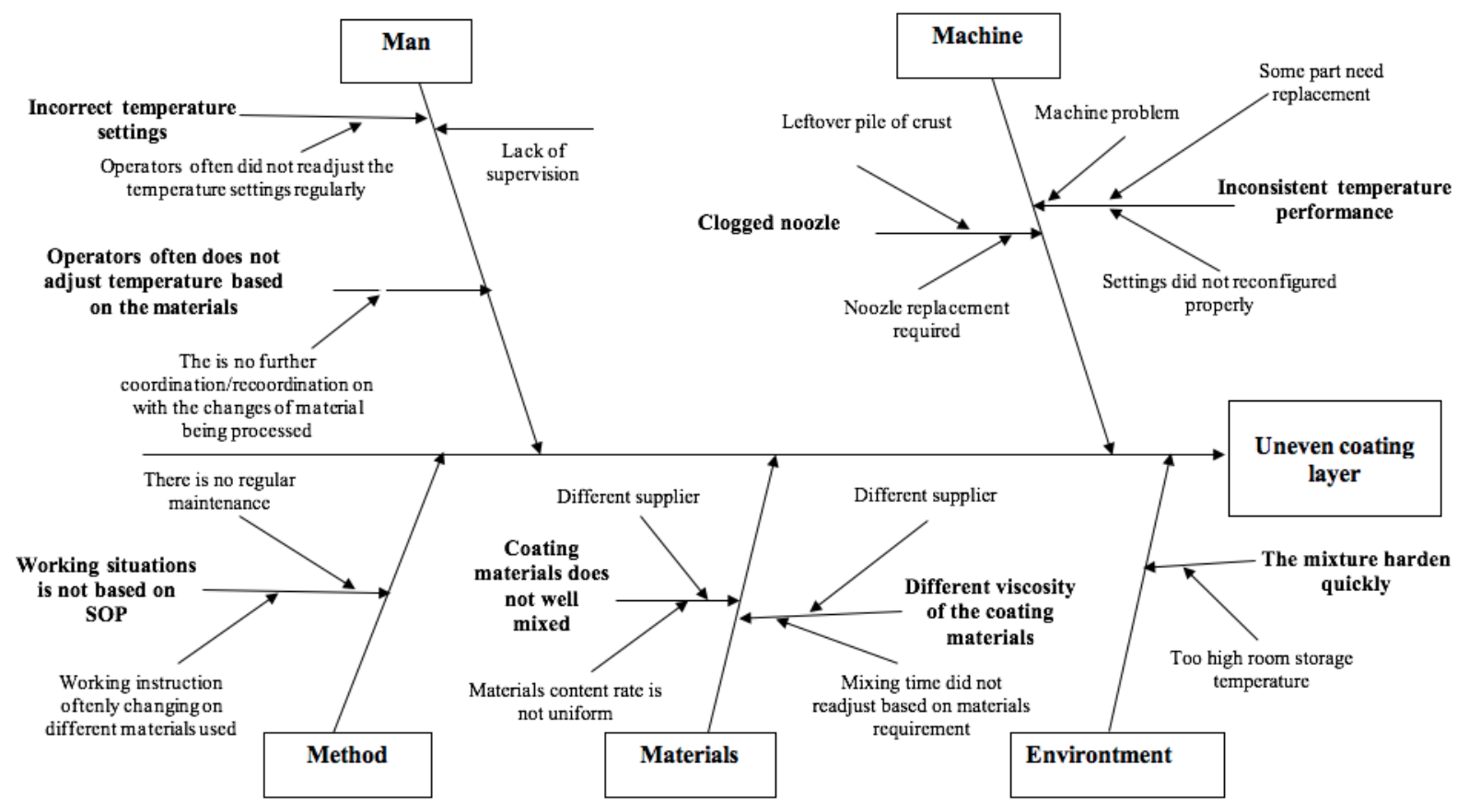

Figure 7. Cause and Effect Diagram of Uneven Coating Layer

Source: Primary data (processed), 2020

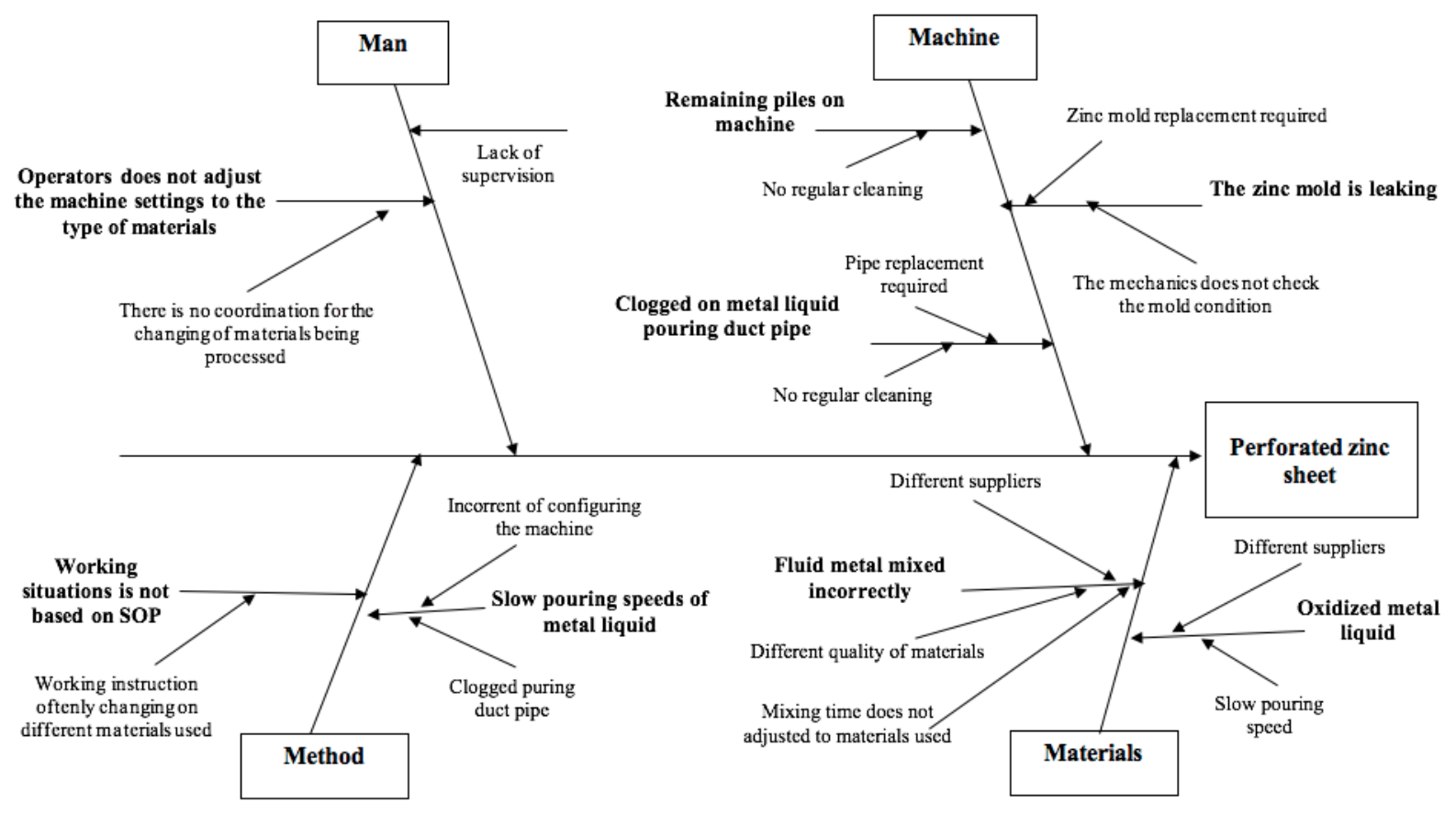

Figure 8. Cause and Effect Diagram of Perforated Zinc Sheet

Source: Primary data (processed), 2020 


\section{Improve}

The Improve stage is a stage to provide recommendations for improvements to overcome the problem found. The model of the $5 \mathrm{~W}+1 \mathrm{H}$ method is used in this improvement stage (Anthony, 2017). Based on the Define, Measure and Analyze analysis, several main factors cause defect products. They are namely Human (Man), Machine, Method, Material, and Environment.

Proposed improvements to the Human factor by providing skills training, performance evaluation, and knowledge on the importance of maintaining quality to employees (Bozionelos et al., 2020; Kelly et al., 2021; Reichler et al., 2020). On the Machine factor, by providing skill training to machine technicians and making regular schedules for maintenance (Bozionelos et al., 2020). And its strongly recommended to perform such routine worn component replacement. In the Method factor, by providing training in understanding the importance of following SOPs, employees understand the function of the SOP itself.

In the Material factor, by marking each raw material which contains certain information or notes, or special treatment for each different. As well as separating raw materials that do not meet QC standards and providing detailed notes (Check Sheet) regarding any standards that these materials cannot meet to do a return. In Environmental factors, the proposed improvement is the intensive monitoring for the room temperature and production machines. This can be done by installing room thermometer sensors in each raw material and production warehouse to perform such effective temperature monitoring.

\section{Control}

At this stage, suggestions in the form of Control Proposal are built. Based on the results of the analysis from the previous stage, and focus deep underdiscusses the Production Manager and representatives from the management, the Control Proposal include:

1. Reset the machine according to the SOP and according to the type of raw material used.

2. Provide training to each operator, such as adjusting settings conveyor belts with press machines and cutting machines, regulating machine temperatures, and checking the type of raw material before use.

3. Ensure that the SOP is adequately implemented and correctly during the production process.

4. Provide skills training to technicians and make check sheets for machine monitoring and check sheets for machine maintenance.

5. Checking configuration needed for the raw materials received before entering the production stage.

6. Marking raw materials based on specifications and suppliers of origin.

\section{CONCLUSION AND RECOMMENDATION Conclusions}

Five factors cause defect products in corrugated zinc production found on this research. The first factor is Human, where at work the employees are less careful when operating machines, poor coordination between SPV and operators and less strict supervision during the production process. The second factor is the Method, at work, employees do not perform procedures according to the SOPs, this is because employees do not fully understand the work procedures in the SOPs.

The third factor is the Machine factor, the machine often does not work normally because there are parts that need to be replaced and there is no regular maintenance performed. The fourth factor is Materials, the quality of the materials is different from each supplier. So, it a must to make some adjustments for each raw material during the production process. The fifth factor is the Environment, where inconsistent room temperature causes changes in the quality of raw materials and cause unintended result in the production stage. 


\section{Recommendation}

By using Six Sigma, company can determine the factors causing defect products on their operations. Then, the company will be able to make corrective policies to fix the problem and minimize the same problem in their future operations. Before the work process begins, it is necessary to have a brief briefing to fully understand the details and work procedures according to the established SOPs (Castro-Rodríguez et al., 2020; Nobori et al., 2014; Park-Lee, 2020). Providing regular training to improve employee skills and work motivation is also necessary to conduct (Bozionelos et al., 2020; Kelly et al., 2021; Reichler et al., 2020).

Employee performance appraisal is also needed to be used as motivation for the employee to perform better and encourage them to compete to give their best productivity (Islami et al., 2018; Nair \& Salleh, 2015; Sanyal \& Biswas, 2014). Communication and further actions with suppliers must be improved so that the quality of raw materials sent is uniform and in accordance with the specifications required by the company. So, the product defects caused by raw materials factors which not comply with company standards can be minimized (Huaccho Huatuco et al., 2020; Saghiri \& Wilding, 2021).

When the production process is running, coordination between supervisor and employees and overall during the production process must constantly be improved so that errors affect quality degradation can be minimized (Afridi et al., 2020). Giving certain marks to the raw materials based on specifications and suppliers of origin and do double checks each time raw materials are received from suppliers to make sure meets the company's quality standard.

\section{REFERENCES}

Afridi, F., Dhillon, A., Li, S. X., \& Sharma, S. (2020). Using social connections and financial incentives to solve coordination failure: A quasi-field experiment in India's manufacturing sector. Journal of Development Economics, 144, 102445. https://doi.org/10.1016/j.jdeveco.2020.102445

Anthony, M. B. (2017). Usulan Penurunan Tingkat Kecacatan Produk Pelat Baja Dengan Metode Six Sigma. 3(2), 41-48.

Ayhari. (2009). Manajemen Produksi (Edisi 4). BPFE.

Bozionelos, N., Lin, C. H., \& Lee, K. Y. (2020). Enhancing the sustainability of employees' careers through training: The roles of career actors' openness and supervisor support. Journal of Vocational Behavior, 117, 103333. https://doi.org/10.1016/j.jvb.2019.103333

Castro-Rodríguez, C., Solís-García, G., Mora-Capín, A., Díaz-Redondo, A., Jové-Blanco, A., LorenteRomero, J., Vázquez-López, P., \& Marañón, R. (2020). Briefings: A Tool to Improve Safety Culture in a Pediatric Emergency Room. Joint Commission Journal on Quality and Patient Safety, 46(11), 617-622. https://doi.org/10.1016/j.jcjq.2020.08.004

Choi, T. M. (2020). Innovative "Bring-Service-Near-Your-Home" operations under Corona-Virus (COVID-19/SARS-CoV-2) outbreak: Can logistics become the Messiah? Transportation Research Part E: Logistics and Transportation Review, 140(April), 101961. https://doi.org/10.1016/j.tre.2020.101961

Davis, D. L. G. \& S. B. (2010). Quality Management for Organizational Excellent Introduction to Total Quality 6 th edition.

Desai, D. (2017). Competitive advantage through Six Sigma at plastic injection molded parts manufacturing unit A case study. 8(4), 411-435. https://doi.org/10.1108/IJLSS-06-2016-0022

Ferreira, J. J. M., Fernandes, C. I., Alves, H., \& Raposo, M. L. (2015). Drivers of innovation strategies: Testing the Tidd and Bessant (2009) model. Journal of Business Research, 68(7), 1395-1403. https://doi.org/10.1016/j.jbusres.2015.01.021

Gaspersz, V. (2005). Total Quality Management. Gramedia Pustaka Utama.

GUAN, J. C., YAM, R. C. M., Tang, E. P. Y., \& Lau, A. K. W. (2009). Innovation strategy and performance 
during economic transition: Evidences in Beijing, China. Research Policy, 38(5), 802-812. https://doi.org/10.1016/j.respol.2008.12.009

Heizer, Jay., dan R. B. (2017). Manajemen Operasi : Manajemen Keberlangsungan dan Rantai Pasokan, Edisi 11. Salemba Empat.

Heizer, J., Render, B., \& Munson, C. (2017). Operations Management (12th ed.). Pearson Education, Inc.

Herron, C., \& Hicks, C. (2008). The transfer of selected lean manufacturing techniques from Japanese automotive manufacturing into general manufacturing (UK) through change agents. Robotics and Computer-Integrated Manufacturing, 24(4), 524-531. https://doi.org/10.1016/j.rcim.2007.07.014

Hsu, M. H., Chang, C. M., \& Chuang, L. W. (2015). Understanding the determinants of online repeat purchase intention and moderating role of habit: The case of online group-buying in Taiwan. International Journal of Information Management, 35(1), 45-56. https://doi.org/10.1016/j.ijinfomgt.2014.09.002

Huaccho Huatuco, L., Smart, J., Calinescu, A., \& Sivadasan, S. (2020). Complexity transfer in suppliercustomer systems. Production Planning and Control, $0(0), 1-13$. https://doi.org/10.1080/09537287.2020.1762135

Indrawati, T., \& Isnaini Dwi Ningsih, N. (2018). PENERAPAN STATISTICS PROCESS CONTROL DALAM PENGAMATAN SIFAT FISIKA DAN KIMIA AIR BUANGAN DARI AIR CONDITIONING (AC) Titik Indrawati 1 dan Nunung Isnaini Dwi Ningsih 2. INTEGRATED LAB JOURNAL, 06, 39-46.

Islami, X., Mulolli, E., \& Mustafa, N. (2018). Using Management by Objectives as a performance appraisal tool for employee satisfaction. Future Business Journal, 4(1), 94-108. https://doi.org/10.1016/j.fbj.2018.01.001

Jirasukprasert, P., Garza-Reyes, J. A., Kumar, V., \& Lim, M. K. (2015). A six sigma and dmaic application for the reduction of defects in a rubber gloves manufacturing process. International Journal of Lean Six Sigma, 5(1), 2-22. https://doi.org/10.1108/IJLSS-03-2013-0020

Kelly, K., Valtchanov, D., \& Webb, A. (2021). Behavioral implications of using an online slot machine game to motivate employees: A cautionary tale. Accounting, Organizations and Society, 89, 101196. https://doi.org/10.1016/j.aos.2020.101196

Kementrian Perindustrian Indonesia. (2020). Daftar Perusahaan Baja di Indonesia.

Kumar, S. A., \& Suresh, N. (2007). Productions and Operations Management (2nd ed.). New Age International Publishers.

Kunamaneni, S., Jassi, S., \& Hoang, D. (2019). Promoting reuse behaviour: Challenges and strategies for repeat purchase, low-involvement products. Sustainable Production and Consumption, 20, 253272. https://doi.org/10.1016/j.spc.2019.07.001

Lyu, Z., Lin, P., Guo, D., \& Huang, G. Q. (2020). Towards Zero-Warehousing Smart Manufacturing from Zero-Inventory Just-In-Time production. Robotics and Computer-Integrated Manufacturing, 64, 101932. https://doi.org/10.1016/j.rcim.2020.101932

Malviya, R. (2021). Agile manufacturing. In Lean Tools in Apparel Manufacturing (pp. 399-421). Elsevier. https://doi.org/10.1016/B978-0-12-819426-3.00011-4

Marques, P. A. de A., \& Matthé, R. (2017). Six Sigma DMAIC project to improve the performance of an aluminum die casting operation in Portugal. International Journal of Quality and Reliability Management, 34(2), 307-330. https://doi.org/10.1108/IJQRM-05-2015-0086 
Martin, J. W. (2008). Operational Excellence: Using Lean Six Sigma to Translate Customer Value through Global Supply Chains. Auerbach Publications.

Nair, M. S., \& Salleh, R. (2015). Linking Performance Appraisal Justice, Trust, and Employee Engagement: A Conceptual Framework. Procedia - Social and Behavioral Sciences, 211, 1155-1162. https://doi.org/10.1016/j.sbspro.2015.11.154

Navío-Marco, J., Bujidos-Casado, M., \& Rodrigo-Moya, B. (2019). Coopetition as an innovation strategy in the European Union: Analysis of the German case. Industrial Marketing Management, 82, 9-14. https://doi.org/10.1016/j.indmarman.2019.05.014

Nobori, J., Ishida, H., Inoue, A., Yoshikawa, T., Kimura, E., \& Ishihara, K. (2014). EPA-0621 - Ultra-short daily briefings for sick-listed employees with psychological problems strengthen the sense of coherence in occupational healthcare. European Psychiatry, 29, 1-2. https://doi.org/10.1016/s0924-9338(14)78001-0

Pande, N., \& Roland R.Cavanagh. (2002). The Six Sigma Way Bagaimana GE, Motorola \& Perusahaan Terkenal Lainnya Mengasah Kinerja Mereka. ANDI.

Park-Lee, S. (2020). Contexts of briefing for service design procurements in the Finnish public sector. Design Studies, 69, 100945. https://doi.org/10.1016/j.destud.2020.05.002

Pete, \& Holpp. (2002). What is Six Sigma. ANDI.

Prendeville, S., \& Bocken, N. (2017). Sustainable Business Models through Service Design. Procedia Manufacturing, 8, 292-299. https://doi.org/10.1016/j.promfg.2017.02.037

Punyawan, S. E., \& Rahardjo, J. (2015). Penurunan Kecacatan di PT Mulcindo Steel dengan Pendekatan Filosofi Six Sigma. 3(1), 7-14.

Pyzdek, T., \& Keller, P. (2013). The Handbook for Quality Management. Mc Graw Hill.

Reichler, S. J., Murphy, S. I., Erickson, A. W., Martin, N. H., Snyder, A. B., \& Wiedmann, M. (2020). Interventions designed to control postpasteurization contamination in high-temperature, shorttime-pasteurized fluid milk processing facilities: A case study on the effect of employee training, clean-in-place chemical modification, and preventive maintenance programs. Journal of Dairy Science, 103(8), 7569-7584. https://doi.org/10.3168/jds.2020-18186

Render, B., \& Heizer, J. (2001). Prinsip-Prinsip Manajemen Operasi. Salemba Empat.

Romdony, J., Lucky, M., \& Rosmandi, N. (2018). Pengaruh Merek, Promosi, dan Kualitas Produk Terhadap Keputusan Pembelian Bola Sepak. Ikhraith-Humaniora, 2, 2.

Saghiri, S., \& Wilding, R. (2021). On the effectiveness of supplier development programs: The role of $\begin{array}{llll}\text { supply-side } \quad \text { moderators. } & 102234 .\end{array}$ https://doi.org/10.1016/j.technovation.2021.102234

Sanyal, M. K., \& Biswas, S. B. (2014). Employee Motivation from Performance Appraisal Implications: Test of a Theory in the Software Industry in West Bengal (India). Procedia Economics and Finance, 11, 182-196. https://doi.org/10.1016/s2212-5671(14)00187-7

Schmuck, R., \& Benke, M. (2020). An overview of innovation strategies and the case of Alibaba. Procedia Manufacturing, 51, 1259-1266. https://doi.org/10.1016/j.promfg.2020.10.176

Sharma, R., Gupta, P., \& Saini, V. (2018). Six Sigma Dmaic Methodology Implementation in Automobile Industry: a Case Study 2. Journal of Manufacturing Engineering, 13(1), 42-050.

Slack, N., Brandon-Jones, A., \& Johnston, R. (2016). Operations Management. In Pearson Education Limited (8th ed.). Pearson Education Limited. 
Suresh, S., \& Vasantha, S. (2021). Influence of logistics service quality among customer satisfaction using IOT based techniques. Materials Today: Proceedings. https://doi.org/10.1016/j.matpr.2020.11.764

Tjiptono, F., dan Diana, A. (2012). Total Quality Management (TQM). Andi.

Tjiptono, F. (2003). Prinsip-Prinsip Total Quality Service. ANDI.

Tremblay, E., Hupper, A., \& Waring, T. M. (2019). Co-operatives exhibit greater behavioral cooperation than comparable businesses: Experimental evidence. Journal of Co-Operative Organization and Management, 7(2), 100092. https://doi.org/10.1016/j.jcom.2019.100092

World Steel Association. (2019). World steel of figure 2020.

Younge, K. A., \& Tong, T. W. (2018). Competitive pressure on the rate and scope of innovation. Journal of Economic Behavior and Organization, 150, 162-181. https://doi.org/10.1016/j.jebo.2018.03.026 